International Journal of Social Science and Economic Research

ISSN: 2455-8834

Volume:05, Issue:09 "September 2020"

\title{
MEDIUM RICE MARKET INTEGRATION IN INDONESIA: REGIONAL DISAGGREGATION ANALYSIS
}

\author{
Jan Piter Sinaga, Muhammad Firdaus, Idha Widi Arsanti, Akhmad Fauzi \\ Food Distribution Staff, Food Distribution and Reserves Center, Food Security Agency, Postgraduate \\ Faculty of Economics and Management, IPB University, Indonesia
}

DOI: 10.46609/IJSSER.2020.v05i09.005 URL: https://doi.org/10.46609/IJSSER.2020.v05i09.005

\begin{abstract}
As a staple food for almost all Indonesian people, rice is a strategic food commodity in Indonesia. This article aims to discuss market integration, the reference market and the formation of medium rice prices using daily data for the period of June 2017 - March 2019. The integration of the medium rice market was analyzed by Johansen's cointegration approach and using the Vector Error Correction Model Panel (VECM Panel). The results showed that there is a longterm relationship among prices at the farmer, wholesaler and consumer levels. However, the level of vertical market integration is not strong enough. Vertical integration of medium rice only occurs in the Java Island region. Spatially, the reference market that is distribution center of medium rice in Indonesia is the Cipinang Rice Main Market (CRMM), Bandung, Makassar, Palembang and Surabaya. Therefore, the government must ensure adequate supply of medium rice to the markets in these cities so that the price of medium rice does not fluctuate significantly.
\end{abstract}

Keywords: Vertical Integration, Spatial Integration, Decomposition Variance, Impulse Response Function, Panel VECM.

\section{INTRODUCTION}

Strategic food prices that are very fluctuating have become the cause of food price volatility and inflation. The main factors causing price fluctuations are due to variations in production between time and among regions, natural disasters, distribution, storage, and limited information (Udoh and Sunday 2007). Profitable prices push more production. However, the majority of farmers have limited capital to respond to price changes (Okoh and Egbon 2005). The efficient marketing of agricultural commodities will benefit producers and consumers because the surplus of production in one place can be channeled to other places that have a deficit with the cost of a fair trade system (Adenegan, 2012). 


\section{International Journal of Social Science and Economic Research}

ISSN: $2455-8834$

Volume:05, Issue:09 "September 2020"

Market efficiency is an equilibrium condition where all profitable opportunities can be utilized by each marketing agent in accordance with the costs incurred. If the inter- market price difference is smaller than the transfer fee, it can be said that the market is running efficiently. However, if the inter-market price difference is greater than the transfer costs, it can be concluded that the market is not efficient (Negassa et al. 2003).

Product marketing from surplus to deficit areas will be efficient if the costs of the trade system are considered appropriate and can benefit producers and consumers (Adenegan, 2012). If the transfer costs are less than the price difference between the two markets, the market is efficient (Negassa et al. 2003). According to Tomek and Robinson (1990), the relationship of a price from a geographically separated market can be analyzed by the concept of spatial market integration using the spatial equilibrium model. According to Barrett and Li (2002), market integration is defined as the ability to sell products between markets where demand, supply, and transaction costs in different markets determine prices and trade flows simultaneously and transmitting price shocks from one market to another. While Sonogo and Amadou (2010) stated that market integration is related to the flow of goods and information, prices, distances, shapes and times that can be defined as trade relations between markets in the process of forming and transmitting prices from one market to another. This means that market integration shows the marketing performance of a commodity.

Spatial market integration has a strong relationship in the trade of food commodities because it is perishable, uneven production while consumption is relatively even and constant, and distances that cause high transportation costs (Sexton et al. 1991). In addition, the functioning of markets and marketing channels are very important in purpose of understanding the impact of various economic policies, such as macroeconomic and trade policies. Spatially segmented markets isolate market participants and limit the transmission of price incentives. Market integration is determined by traders' behavior and market conditions, transportation infrastructure, communication, and storage areas which cause high marketing margins (Goletti et al, 1995).

Government policies can also affect markets through price stabilization policies, trade restrictions, and regulations related to transportation. Rapsomanikis et al (2004) stated that oligopoly and collusion behavior among traders are determinants of market integration. Traders can maintain price differences between markets at a higher level than transfer fee.

In the territorial context, unfavorable trade flow structures between regions causes prices to fluctuate. Price volatility can be seen from the coefficient of variation in food commodities in each region. The difference in the coefficient of variation in each region shows that the ability of each region to reduce price fluctuations is different. Volatility and price variants that are not too large are factors that make effective price stabilization policies (Borensztein, 1994).

Central and regional government price stabilization policies require an understanding of food price issues that need attention due to policy issues and interest in decision making. Government ability in making appropriate pricing policies are determined by an understanding of market 


\section{International Journal of Social Science and Economic Research}

ISSN: $2455-8834$

Volume:05, Issue:09 "September 2020"

structure, behavior, and effectiveness, which are described by the degree of market integration between regions, enabling policy makers to respond to price shocks that occur (Firdaus and Gunawan, 2012; Tsimpo and Wodon, 2008).

An understanding of the aspects of good market integration helps policymakers formulate policies that benefit producers and consumers. The understanding is related to how the integration of the medium rice market, the influence of the main market of medium rice in each region, and how the implications for government policies. Based on this, the objective of this paper is to analyze the structure, behavior and market effectiveness described by the integration of the Sumatra and Java medium rice market, and the territory of Indonesia. The results of the analysis can be input for national and inter-regional rice policy formulations.

\section{METHODOLOGY}

\section{Framework}

Some of the problems in marketing agricultural products are weak infrastructure, inadequate market information, scale of agricultural product markets that relatively small, farmers' lack of knowledge about grading and handling, and high transaction costs. High transaction costs faced by farmers in developing countries are mainly due to high transportation costs as a result of the distance from production centers to consumption centers, poor road conditions, and payment for services to intermediary traders (Makhura and Mokoena 2003). The concept of marketing efficiency is closely related to the concept of market integration (Sharp and Uebele 2013). The operational definition of market integration is known as the Law of One Price (LOP) (Edi et al, 2014; Zunaedah et al. 2015; Gluschenko, 2018). LOP states that the same product is sold at relatively the same price in various markets, only distinguished by transportation costs (Monke and Petzel, 1984; Crucini et al. 2010). Market integration refers to the long-term relationship among prices (Ghafoor et al. 2012). Market integration is also a signal of price transmission and information about inter-market linkages that are separate (Golleti et al. 1995). Analysis of market prices increases understanding related to price signals, change direction, and transmission of prices from production centers to consumption areas.

\section{Data Analysis Methods}

In contrast to previous studies which generally use time series data with linear regression analysis models, this study used regency/city panel price data in the Sumatra, Java and other regions with the Panel Vector Autoregression (PVAR) analysis model. Analysis of the integration of the medium rice market was carried out by disaggregation of regions based on Sumatra and Java Island regions. Analysis by region was then compared with the results of the national analysis to determine differences in regional integration and national aggregate 
integration. Therefore, overall there were 3 analysis models, i.e., Indonesia, Sumatra and Java. Market integration analysis was carried out through unit root tests and cohesive tests or cointegration tests. Unit root test was performed to determine the stationarity of panel data used in the model and to determine the order of the stationarity of the data. The cohesion test was carried out to identify the short-term and long-term linkages and relationships of time series data. Detection of the cointegration existence was performed by the Ravallion (1986), Engle and Granger (1987), or Johansen (1988) models. The Panel Error Vector Correction Model (Panel VECM) was used because there was cointegration. The VECM (k) panel of this study was the development of the usual VAR/VECM model with the general form of the equation as follows:

$$
\Delta \mathrm{yt}_{\mathrm{t}}=\delta \mathrm{dt}+\alpha \beta^{\prime} \mathrm{yt}_{\mathrm{t}-1}+\Gamma \mathrm{X}_{\mathrm{t}}+\varepsilon \mathrm{t} \quad \quad \text { untuk } \mathrm{t}=1,2,3, \ldots \ldots . \mathrm{T}
$$

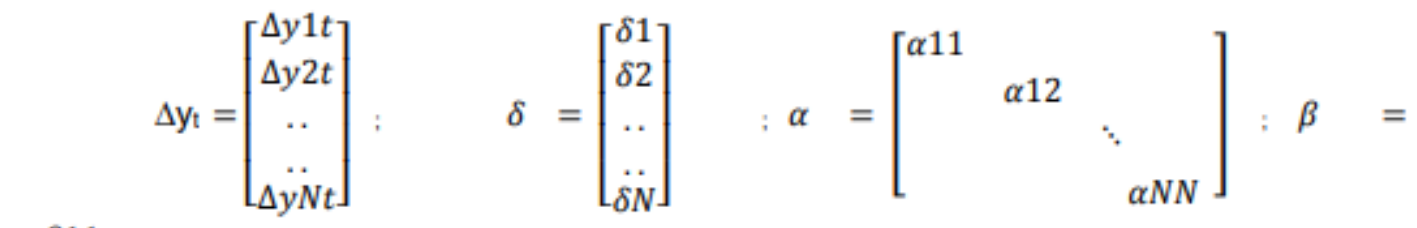

$\left[\begin{array}{llll}\beta 11 & & & \\ & \beta 12 & & \\ & & \ddots & \\ & & & \beta N N\end{array}\right]$

$$
\begin{aligned}
& \Delta \mathrm{y}_{\mathrm{t}-1}=\left[\begin{array}{c}
\Delta y 1 t-1 \\
\Delta y 2 t-1 \\
. . \\
. \\
\Delta y N t-1
\end{array}\right] ; \Gamma=\left[\begin{array}{cccc}
\Gamma 11 & \Gamma 12 & \ldots & \Gamma 13 \\
\Gamma 21 & \Gamma 22 & \ldots & \Gamma 23 \\
\vdots & \vdots & \vdots \\
\Gamma N 1 & \Gamma N 2 & \Gamma N N
\end{array}\right] ; \quad \mathrm{xt}=\left[\begin{array}{c}
X 1 t \\
X 2 t \\
. . \\
. \\
X N t
\end{array}\right] ; \varepsilon_{\mathrm{t}}=\left[\begin{array}{c}
\varepsilon 1 t \\
\varepsilon 2 t \\
. . \\
. \\
\varepsilon N t
\end{array}\right] ; \quad \mathrm{y}_{\mathrm{t}}= \\
& {\left[\begin{array}{c}
\text { Grosir it } \\
\text { HGKP it } \\
\text { Ec }(B, E, C, D, E) \text { it }
\end{array}\right]} \\
& \therefore .
\end{aligned}
$$

\footnotetext{
Note:

$\Delta y_{\mathrm{t}} \quad=$ matrix difference $\mathrm{p}$ of observed variables

$\Delta \mathrm{yt}-1=$ matrix lag 1 observed variables

$\delta \quad=$ parameter matrix of model determinant components

$\mathrm{dt} \quad=$ determinant component vector $(\mathrm{t})$

$\alpha \beta^{\prime} \quad=$ coefficient matrix of long-term equation

$\alpha \quad=$ matrix of diagonal adjustment

$\beta \quad=$ matrix of diagonal cointegration

$\Gamma \quad=$ dynamic matrix of short-term equation

$\mathrm{X}_{\mathrm{t}}=$ difference matrix observed in the lag operator $(\mathrm{k})$
} 


\section{International Journal of Social Science and Economic Research}

ISSN: $2455-8834$

Volume:05, Issue:09 "September 2020"

$\varepsilon_{\mathrm{t}} \quad=$ error term matrix

Eceran $_{\mathrm{it}}=$ retail price of regency/city (i) in the period (t) $(\mathrm{IDR} / \mathrm{kg})$

Grosirit $=$ wholesale price of regency/city (i) in the period (t) (IDR/kg)

$\mathrm{HGKP}_{\text {it }}=\mathrm{GKP} /$ producer price of regency/city (i) in the period $(\mathrm{t})(\mathrm{IDR} / \mathrm{kg})$

$\mathrm{Ec}(\mathrm{B}, \mathrm{C}, \mathrm{D}, \mathrm{E}, \ldots .)=$. retail prices in big city $(\mathrm{B}, \mathrm{C}, \mathrm{D}, \mathrm{E} \ldots)$ in the period $(\mathrm{t})(\mathrm{IDR} / \mathrm{kg})$

There were 18 regencies/cities in Sumatra Island regional analysis model, 21 regencies/cities in Java Island regional analysis model and 24 regencies/cities in the other regional analyses. Therefore, in the Indonesia aggregate analysis model, there were 63 regencies/cities that are the unit of analysis. The prices of producers and consumers of large cities in each region included in the model were carried out with consideration of the surplus/deficit conditions, Gross Regional Domestic Product (GRDP), and the spatial interaction relationships with regencies/cities within and outside the regions. Meanwhile, the CRMM price was included in all regional models to determine the magnitude of market influence that was considered as the main reference and the comparison of its influence with the rice markets of major cities in each of these regions.

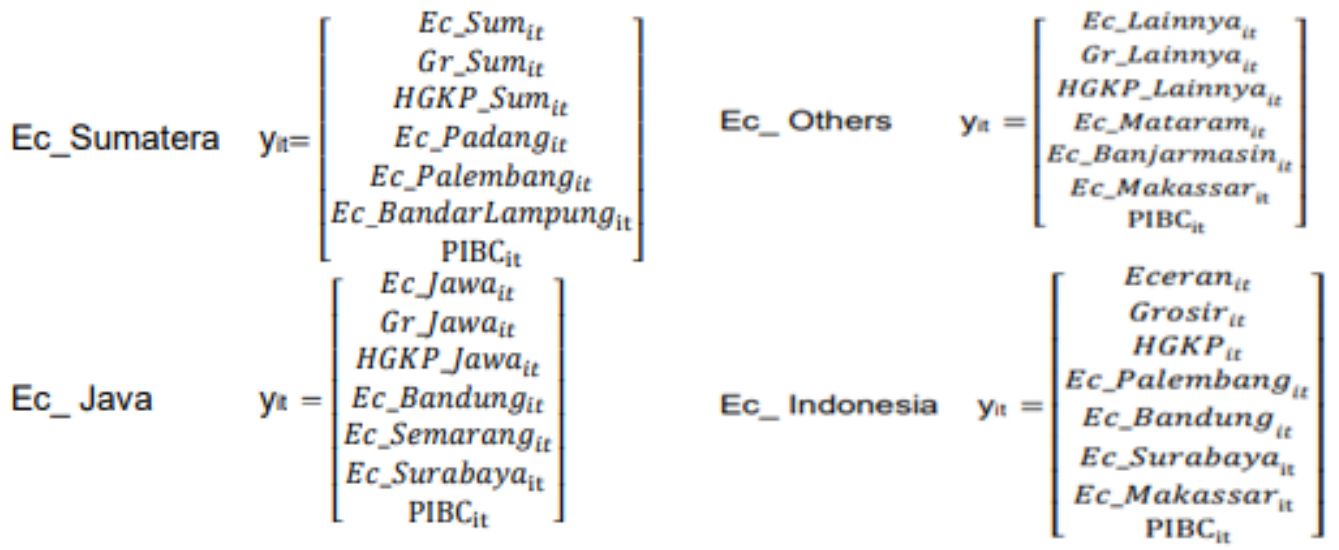

Note:

Ec_Sum $/ \mathbb{l}=$ retail price of regency/city of Sumatra (i) in the period (t) $($ IDR $/ \mathrm{kg})$

$\mathrm{Gr}_{\text {SSum }}$ it $=$ wholesale price of regency/city of Sumatra (i) in the period (t) (IDR/kg)

HGKP_Sumit $=$ GKP price of regency/city (i) in the period (t) $($ IDR $/ \mathrm{kg})$

Ec_Pdng $t_{t}=$ retail price in Padang city in the period $(\mathrm{t})(\mathrm{IDR} / \mathrm{kg})$

Ec_Pdng $_{t}=$ retail price in Palembang city in the period $(\mathrm{t})(\mathrm{IDR} / \mathrm{kg})$

Ec_Blam $\mathrm{t}_{\mathrm{f}}=$ retail price in Bandar Lampung city in the period (t) $(\mathrm{IDR} / \mathrm{kg})$

Ec_Jawa $=$ retail price of regency/city of Java (i) in the period (t) (IDR/kg)

$\mathrm{Gr}_{\text {_Jawa }}$ = wholesale price of regency/city of Java (i) in the period (t) $(\mathrm{IDR} / \mathrm{kg})$

HGKP_Jawa ${ }_{\mathrm{it}}=\mathrm{GKP}$ price of regency/city (i) in the period $(\mathrm{t})(\mathrm{IDR} / \mathrm{kg})$

Ec_Band $t=$ retail price in Bandung city in the period $(\mathrm{t})(\mathrm{IDR} / \mathrm{kg})$

Ec_Smrg $t=$ retail price in Semarang city in the period $(\mathrm{t})(\mathrm{IDR} / \mathrm{kg})$

Ec_Sbyat $=$ retail price in Surabaya city in the period $(\mathrm{t})($ IDR/ $/ \mathrm{kg})$

$E_{c}$ LLainnya $a_{t t}=$ retail price of regency/city of other regions (i) in the period $(t)(I D R / k g)$

$\mathrm{Gr}_{-}$Lainnya $_{i t}=$ wholesale price of regency/city of other regions $(\mathrm{i})$ in the period (t) (IDR/kg) 
International Journal of Social Science and Economic Research

ISSN: 2455-8834

Volume:05, Issue:09 "September 2020"

\section{Data Collection}

This study used data in the form of price data panel at producer levels, retail and wholesale prices of regency/city published by the Food Security Agency, Ministry of Agriculture and Strategic Food Price Information Center from July to March 2019. Producer data was obtained from Food Price Panel data of the Food Security Agency, Ministry of Agriculture, while price data at the wholesale and retail level was obtained from the Strategic Food Price Information Center.

\section{RESULTS AND DISCUSSION}

\section{Model Validation}

Time series data are generally not stationary (Pavel and Barry 2005). Data in the form of time series are said to be stationary if the mean and variation are constant over time (Vasciaveo et al. 2013). Data that is not stationary will produce a spurious regression equation, so the estimated parameter generated is not stable (Granger and Newbold, 1974). The approach taken to overcome the pseudo-regression equation is to differentiate the data series used, so that a stationary variable is obtained with the first degree. Market integration and price transmission are indicators to measure market performance. Spatial market integration measures the relationship between two geographically separated market locations that will have the same long-term price and are only distinguished by distribution costs and marketing margins (Ardeni 1989).

Table 1. Panel unit root test

\begin{tabular}{|c|c|c|c|c|c|c|c|c|c|c|c|c|c|}
\hline \multirow[b]{2}{*}{ Variubel } & \multirow[b]{2}{*}{ Senbol } & \multicolumn{6}{|c|}{ Level } & \multicolumn{6}{|c|}{ Feat Diffactace } \\
\hline & & $\begin{array}{l}\text { Levin, Lin } \\
\text { AC Chu Test } \\
\text { Statbiac: }\end{array}$ & $\rho$ value & $\begin{array}{l}\text { ADF Tos } \\
\text { Stustix }\end{array}$ & pralue & $\begin{array}{l}\text { PP Test } \\
\text { Stustic }\end{array}$ & $\rho$ value & 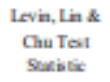 & pvalue & $\begin{array}{l}\text { ADE } \\
\text { Tot } \\
\text { Stasiste }\end{array}$ & prolue & $\begin{array}{l}\text { PPTot } \\
\text { Seatibtic }\end{array}$ & $\rho$ value \\
\hline I Hroga Everan Pudang & Es_Pdg & 603 & 1,00 & 1,45 & 1,00 & 2,27 & 1,00 & \multicolumn{2}{|c|}{$-23,750000^{*}=$} & 991 & $0000+\cdots$ & 3.177 & $00000 *$ \\
\hline 2 Hrga Eseran BLarapung & Es_Blmm & ans & 0,19 & 17,99 & 0,99 & 7,63 & 1,00 & \multicolumn{2}{|c|}{-30 his $0000 \%$} & 5 & $0000 \%$ & 3.184 & $00000 *$ \\
\hline 3 Hrga Everan Sumaven & Ee_Sum & $-1,17$ & 0,12 & 27,9 & 0.84 & \multicolumn{2}{|c|}{$90,90000 * 4$} & \multicolumn{2}{|c|}{$9520000 *$} & 1.071 & $0000 * .$. & 2.256 & 00000 \\
\hline 4 Hrga CKP_Sum & CKP_Sum & -3.61 & acoorw. & 59,96 & $0007 * *$ & 3297 & $0000 * *$ & & & & & & \\
\hline 5 Hrga Gruir Sumwen & Gr_Sem & 3.22 & 099 & 9,44 & 1,00 & 7,93 & 1,00 & \multicolumn{2}{|c|}{$-35,910000^{* * *}$} & 1.151 & $0000 \% .$. & 2.860 & $0000=$ \\
\hline 6 Hirga PIBC & H_PBC & -0.23 & 0,41 & 20,07 & 1,00 & 11,59 & 1,00 & 44,3 & 1,00 & 1.200 & $0000 \%$ & 2.599 & $0000=$. \\
\hline 7 Hinga Eseran Hasdung & Ee_Hand & 394 & 100 & 4,71 & 100 & 6.39 & 100 & 33,16 & 100 & 1.048 & $00000 . .1$ & 3.326 & $00000=$ \\
\hline 8 Hrga Eceran Scrmarang & Ee_Simg & 239 & $Q 99$ & 798 & 1,00 & 2,99 & 100 & \multicolumn{2}{|c|}{$-37,440000 \%$} & 1.268 & $0000+.$. & 3.618 & $00000=$ \\
\hline 9 Hinga Eceran Surakuya & Ee_sbya & 3.7 & Q999 & 6,16 & 1,00 & 6,77 & 1,00 & \multicolumn{2}{|c|}{$-29,350000 \%$} & seto & 10000"... & 3.777 & $0000=$ \\
\hline 10 Hrya Eseran Java & EC_Jawa & -2.66 & acoser. & 35,86 & 0,74 & 41,33 & as & \multicolumn{2}{|c|}{$-6,610000 *$} & 500 & $0000+\cdots$ & 2.735 & $00000=$ \\
\hline II Hirga Grosis lava & G lawa & -1.06 & 0,14 & 29,02 & 0,94 & 37,8 & 0,66 & \multicolumn{2}{|c|}{$16,90000 \%$} & 644 & $00000 .$. & 2.748 & $0,000=0$ \\
\hline 12 Hrga CKP_Jawa & CKP_Java & -5.58 & $0 \omega 0^{*} *$ & \multicolumn{2}{|c|}{795000000.} & 76,43 & $0000 \times$ & & & & & & \\
\hline 13 Hrga Escran Mataram & Ee_Mtrm & 279 & $Q 99$ & 7,98 & 1,00 & 2,35 & 100 & \multicolumn{2}{|c|}{$-39610000 \%$} & 1.413 & $0000+\cdots$ & 3.794 & $0000=1$ \\
\hline 14 Hrga Eseran Hanjarmasin & Ec_Bjm & -290 & 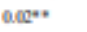 & 36,04 & ass & 29,63 & $Q 97$ & \multicolumn{2}{|c|}{$-45,300000 \%$} & 1.729 & $0000+.$. & 2.765 & $00000=$ \\
\hline is Hirga Escran Mabssiz & Es Mat & -0.36 & 0,36 & 19,3 & Q,99 & 9,31 & 100 & \multicolumn{2}{|c|}{$-24,230000 \%$} & & $50000 \%$ & 3.965 & $00000=$ \\
\hline 16 Hrya Grusi Lainay & G_Lain & -0.30 & 0,38 & \multicolumn{2}{|c|}{$65,28003 * *$} & \multicolumn{2}{|c|}{$728460007 * *$} & & & & & & \\
\hline 17 Hrya CKP Lainnya & CKP Lain & $-3,0$ & $0,000^{* *}$ & 71,80 & $000 x=*$ & 10086 & $0.000 \% *$ & & & & & & \\
\hline
\end{tabular}

Keterangan:

**) : signifikan pada $\rho=5 \%$

$* * *)$ : signifikan pada $\rho=1 \%$ 


\section{International Journal of Social Science and Economic Research}

ISSN: $2455-8834$

Volume:05, Issue:09 "September 2020"

The panel unit root test using Levin, Li \& Chu, Augmented Dicky Fuller (ADF) and Philip Peron showed that producer prices (GKP) and wholesale prices in other regions were stationary at the level, while retail and wholesale prices were not stationary at the level. This is because in the unit root test at retail and wholesale prices, the $\mathrm{p}$ value is less than the critical value at the real level of $5 \%$ and $10 \%$. After the first differentiation was performed on all prices, the test results showed that all prices were stationary at the same level so that the resulting regression equation was not spurious (Table 1).

Table 2. Result of cointegration test

Beras Medium Sumatera

Unrestricted Cointegration Rank Test

\begin{tabular}{|c|c|c|c|c|}
\hline $\begin{array}{l}\text { Hypothesized } \\
\text { No. of CE (s) }\end{array}$ & $\begin{array}{c}\text { Fisher Stat" (from } \\
\text { trace test) }\end{array}$ & Prob & $\begin{array}{c}\text { Fisher Stat }{ }^{*} \text { (from } \\
\text { max-eigen test) }\end{array}$ & Prob \\
\hline None ${ }^{* *}$ & 183.3 & 0.0000 & 184.3 & 0.0000 \\
\hline At most $1^{* *}$ & 61.87 & 0.0000 & 74.22 & 0.0000 \\
\hline At most 2 & 20.82 & 0.8934 & 32.94 & 0.3252 \\
\hline \multicolumn{5}{|c|}{$\begin{array}{l}\text { Beras Medium Jawa } \\
\text { Unrestricted Cointegration Rank Test }\end{array}$} \\
\hline $\begin{array}{l}\text { Hypothesized } \\
\text { No. of CE (s) }\end{array}$ & $\begin{array}{c}\text { Fisher Stat } \\
\text { trace test) }\end{array}$ & Prob & $\begin{array}{c}\text { Fisher Stat }{ }^{*} \quad \text { (from } \\
\text { max-eigen test) }\end{array}$ & Prob \\
\hline None ${ }^{* *}$ & 280.6 & 0.0000 & 335.1 & 0.0000 \\
\hline At most $1^{* *}$ & 83.57 & 0.0000 & 126.5 & 0.0000 \\
\hline At most 2 & 26.26 & 0.8259 & 36.25 & 0.3641 \\
\hline \multicolumn{5}{|c|}{$\begin{array}{l}\text { Beras Medium lainnya } \\
\text { Unrestricted Cointegration Rank Test }\end{array}$} \\
\hline $\begin{array}{l}\text { Hypothesized } \\
\text { No. of CE (s) }\end{array}$ & $\begin{array}{c}\text { Fisher Stat* (from } \\
\text { trace test) }\end{array}$ & Prob & $\begin{array}{l}\text { Fisher Stat" (from } \\
\text { max-eigen test) }\end{array}$ & Prob \\
\hline None ${ }^{* *}$ & 176.0 & 0.0000 & 193.6 & 0.0000 \\
\hline Atmost $1^{* *}$ & 52.51 & 0.0000 & 98.29 & 0.0000 \\
\hline At most 2 & 11.83 & 1,0000 & 28.28 & 0.8171 \\
\hline
\end{tabular}

Beras Medium Indonesia

Unrestricted Cointegration Rank Test

\begin{tabular}{ccccc}
\hline $\begin{array}{c}\text { Hypothesized } \\
\text { No. of CE (s) }\end{array}$ & $\begin{array}{c}\text { Fisher Stat } \\
\text { trace test) }\end{array}$ & Prob & $\begin{array}{c}\text { Fisher Stat } \\
\text { max-eigen test) }\end{array}$ & Prob \\
\hline None $^{* *}$ & 2090.0 & 0.0000 & 1317 & 0.0000 \\
At most 1 ${ }^{* *}$ & 949.5 & 0.0000 & 749.6 & 0.0000 \\
At most 2 & 383.5 & 0.0001 & 421.8 & 0.0000 \\
Atmost 3 & 121.0 & 0.1851 & 175.6 & 0.0000 \\
\hline
\end{tabular}

Keterangan

* ) : probabilities are computed using as ymptotic Chi-square distribution $* *)$ : denotes rejection of the hypothesis at the 0.05

Cointegration test was carried out to identify short-term and long-term linkages and relationships of panel data. Detection of the cointegration existence can be performed by the Ravallion (1986), Engle and Granger (1987), or Johansen (1988) models. Johansen Fisher Panel Cointegration Test was conducted to determine whether or not cointegration existed. Cointegration will correct variable fluctuations in the short-term towards stability in the long-term balance. Based on the 
International Journal of Social Science and Economic Research

ISSN: 2455-8834

Volume:05, Issue:09 "September 2020"

results of the cointegration test described in Table 2, there are 2 (two) cointegrations in the regional analysis of Sumatra, Java and others; while in the analysis of Indonesia, there are 3 (three) cointegration equations. This shows that in this research model, there was a long-term cointegration so that the Panel Vector Error Correction Model (Panel VECM) was chosen as an estimation tool.

Based on the cointegration test results above, it is shown that the trace statistic value and maximum eigenvalue at rank $=1$ are greater than critical value with a significance level of $5 \%$ in the regional analysis of Sumatra, Java and others. Meanwhile, in Indonesia analysis, the value of trace statistic and maximum eigenvalue at rank $=2$ are greater than critical value with a significance level of $5 \%$. This means that the null hypothesis which stated that there is no cointegration was rejected and the alternative hypothesis which stated that there is a cointegration is accepted, so it can be said that all variables had a significant long-term relationship. Based on the cointegration test, it is shown that the medium rice market is spatially integrated. There are two cointegration vectors between retail prices in markets of Sumatra, Java and others. Medium rice prices have a long-term equilibrium relationship and there is a strong integration among medium rice markets, so prices in one market can be used to predict prices in other markets. Spatial integration analysis for the market of agricultural products has been widely carried out, for example, Firdaus and Gunawan (2012) and Katrakilidis (2008).

\section{Production Performance, Consumption and Surplus Deficit of Indonesian Rice}

Indonesian rice production based on the data collection of Analysis Sample Framework, the Central Bureau of Statistics (BPSb, 2018), from January to September 2018 was 49.65 million tons of Milled Dry Grain (MDG). The highest production occurred in March of 9.46 million tons, while the lowest production was in January of 2.71 million tons. Rice production potential in October, November and December was 2.66 million tons, 2.10 million tons and 2.13 million tons, respectively. Therefore, the estimated total rice production in 2018 was 56.54 million tons. If converted to rice with the conversion rate of MDG to rice in 2018 was equivalent to 28.47 million tons of rice. Taking into account the production potential up to December 2018, the estimated total rice production in 2018 was 32.42 million tons. 


\section{International Journal of Social Science and Economic Research}

ISSN: $2455-8834$

Volume:05, Issue:09 "September 2020"

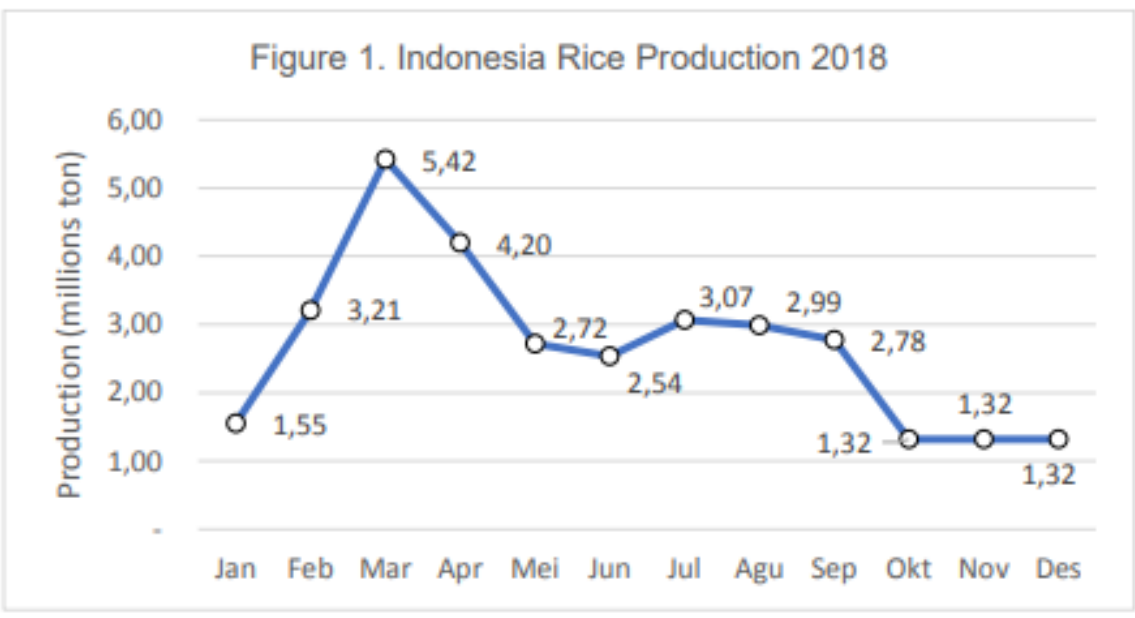

The rice production in 2018 was concentrated in the regions of Java and Sumatra. Rice production in these two islands reached $75 \%$ of Indonesia's total rice production. Sulawesi Island was the next island that contributed to rice production with a share of $14 \%$ of Indonesia's total rice production. Other regions only contributed around $11 \%$ of the total production (Figure 2).

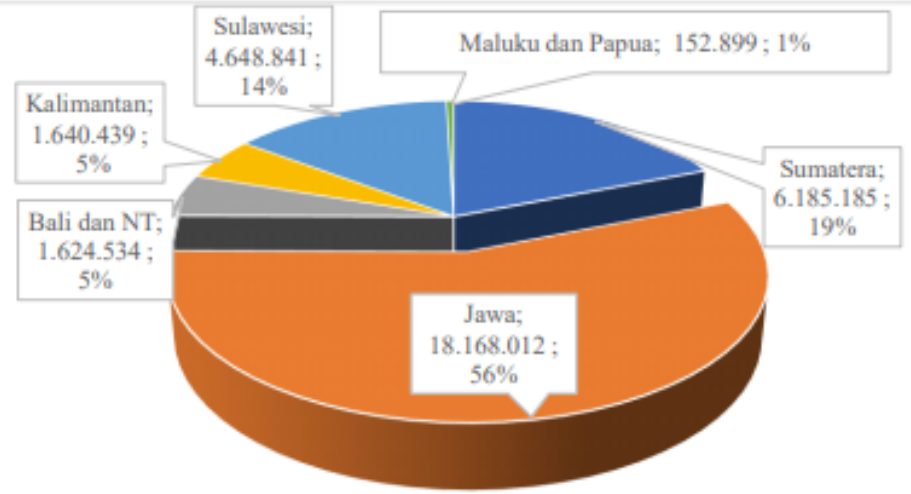

Produksi Beras Indonesia $2018=\mathbf{3 2 . 4 1 9 . 9 1 0}$ ton

This is consistent with data showing that the 10 highest rice producing provinces are in these three islands (Figure 3). Only the provinces of South Sulawesi, West Nusa Tenggara and South Kalimantan are among the biggest rice-producing provinces outside of Java and Sumatra Islands. The five provinces with the highest rice production are East Java, West Java, Central Java, South Sulawesi and South Sumatra, with production of 6.05 million tons, 5.48 million tons, 5.44 million, 3.28 and 1.51 million tons, respectively. Rice production in these five provinces reached $67.14 \%$ of Indonesia's total rice production. 
International Journal of Social Science and Economic Research

ISSN: 2455-8834

Volume:05, Issue:09 "September 2020"

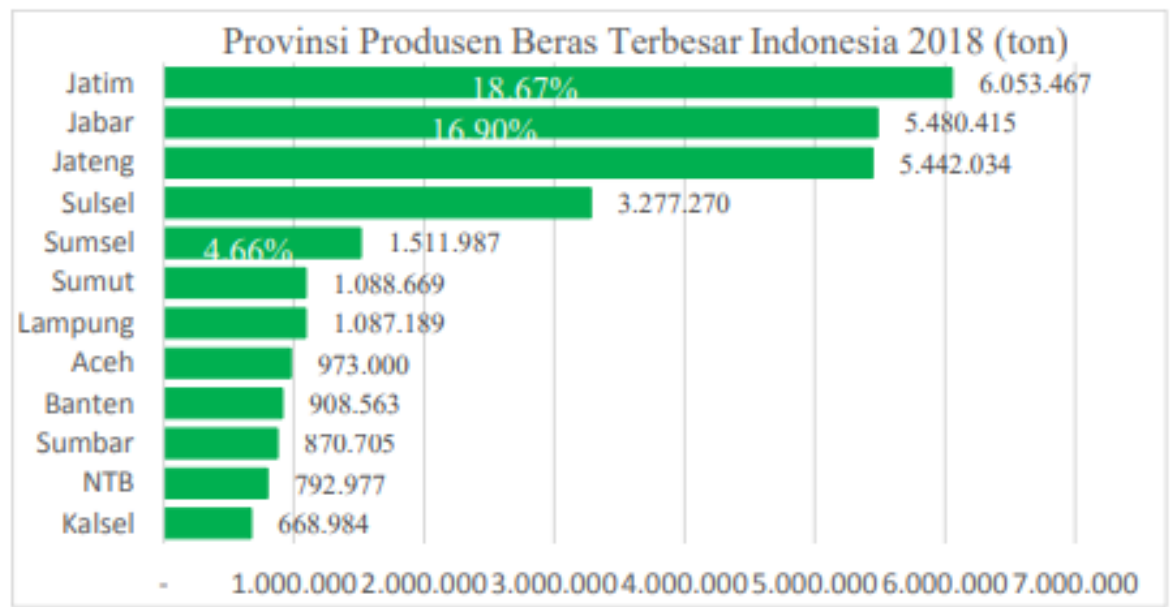

Unlike the rice production in certain regions, rice consumption is evenly distributed throughout Indonesia. The variation in production areas is in accordance with the potential of different regional resources. On the other hand, consumption is spread evenly because almost all of Indonesian population's staple food is rice.

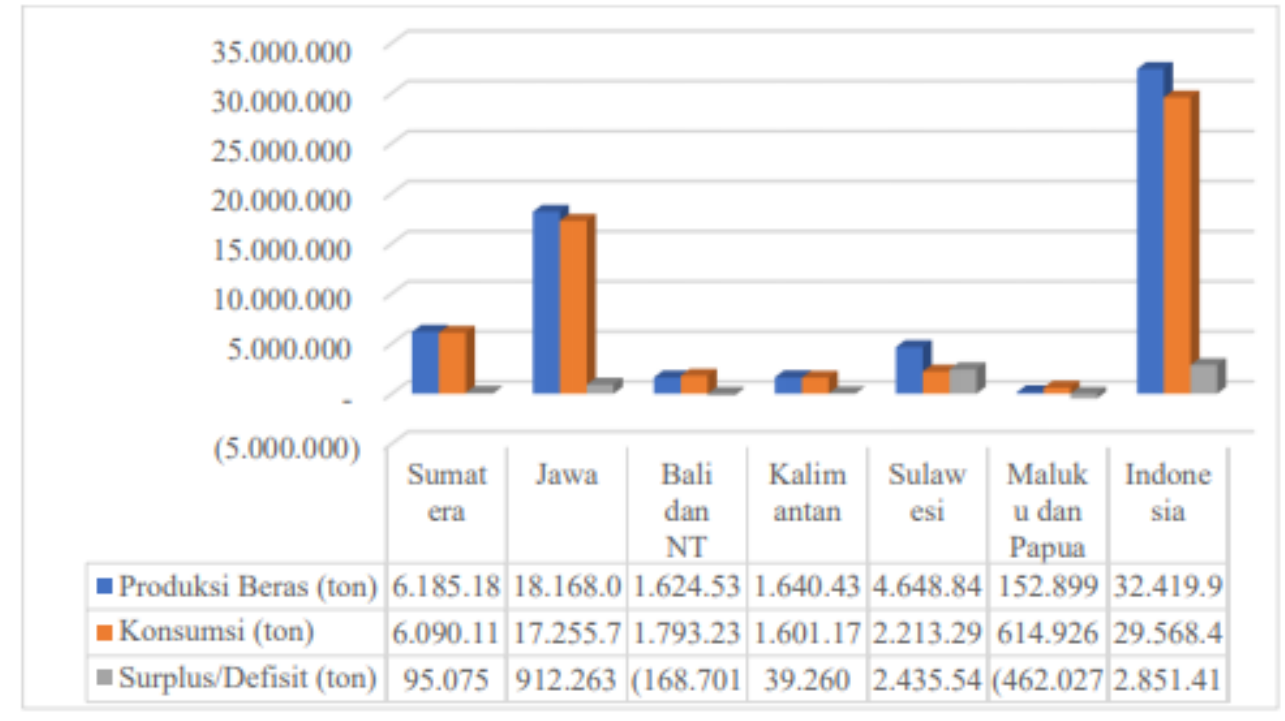

When using the national average rice consumption per capita of $111.58 \mathrm{~kg} / \mathrm{capita} / \mathrm{year}$, the total national rice consumption in 2018 was below the total production of 29.57 million tons. Even though in national aggregate rice production has a surplus, but if analyzed in a disaggregate per large island, the regions of Bali and Nusa Tenggara, Maluku and Papua have a deficit. While rice production in Kalimantan Island is relatively the same as the cumulative consumption in 2018. In accordance with the population, the largest rice consumption is in Java Island at 17.26 million tons $(58.36 \%)$ and Sumatra Island (20.60\%). Rice consumption in Sulawesi Island is far below its 
production amounts. Total consumption is only 2.21 million tons, which means there is an excess of rice production in the region of 2.43 million tons or around $85.41 \%$ of the total national surplus of 2.85 million tons.

The condition of the deficit surplus per Province shows that almost all provinces of rice production centers have a surplus while the non-production provinces have a deficit. However, the provinces of West Java and North Sumatra, which were aggregate production centers in 2018, experienced a deficit due to the amount of consumption that was greater than the production capacity. West Java Province's rice production of 5.48 million tons was still smaller than the total consumption of 6.25 million tons, resulting in a deficit of 0.77 million tons. The deficit in rice production in North Sumatra Province was 0.56 million tons because its production was 1.09 million tons smaller than the consumption of its population which amounted to 1.65 million tons.

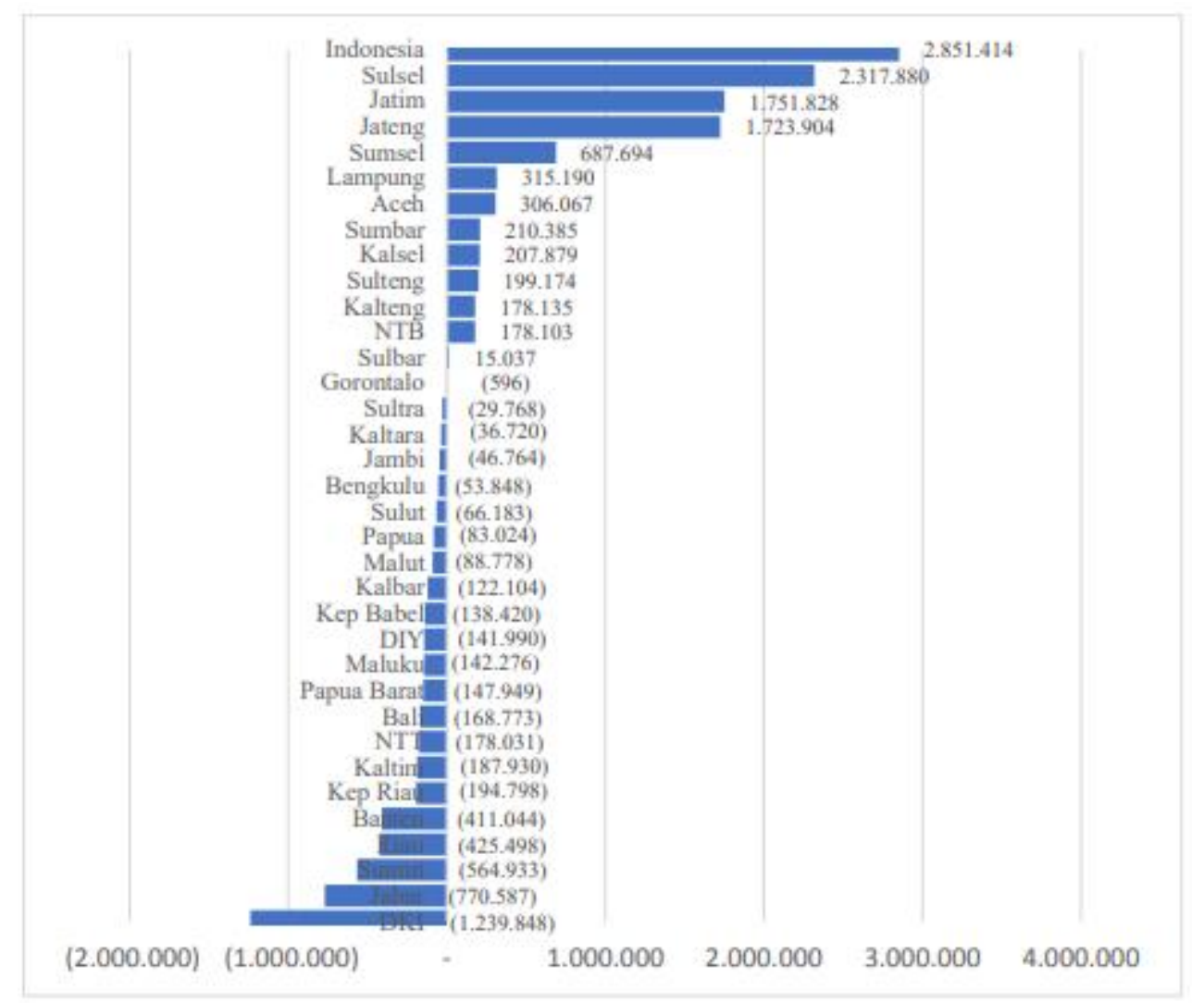

DKI Jakarta Province is the province with the largest amount of rice production deficit (1.24 million tons) because the fulfillment of population rice consumption needs in the capital region is entirely obtained from the production of other provinces. Meanwhile, provinces outside Java, Sumatra and Sulawesi Islands are deficit regions, except West Nusa Tenggara, South Kalimantan 
International Journal of Social Science and Economic Research

ISSN: 2455-8834

Volume:05, Issue:09 "September 2020"

and Central Kalimantan (Figure 5).

Medium Rice Market Integration

\section{Sumatra}

The retail price of Sumatra's medium rice is responsive to the wholesale and GKP price shock. Wholesale and retail prices respond positively to each other. Retail prices started to respond to wholesale price shocks from the beginning of the period until the 10th period and wholesale prices began to respond to retail price shocks in the 4 th period. The GKP price shock was only responded positively by the retail price briefly which then declined after the 4th period, while the wholesale price tended not to respond to the GKP price shock. The IRF results were in accordance with the FEDV test which showed that retail prices affected the wholesale price (0.819) and the GKP (0.408), while the wholesale price and GKP did not affect retail prices in Sumatra (Table 3).

Table 3. The Linkage of Retail Medium Rice Prices in Big Cities in Sumatra Island

\begin{tabular}{|c|c|c|c|c|c|c|c|c|}
\hline No & Variabel & $\begin{array}{l}\text { Variance } \\
\text { Period }\end{array}$ & PIBC & Ec_Padang & Ec_Palembang Ec_ & B.Lampung & Eceran & Harga GKP \\
\hline 1 & Ec_Bandar hmpung & 10 & 1.072 & & 1.494 & & 0.231 & \\
\hline 2 & Ec_Padang & 10 & 9.364 & & 0.889 & 0.402 & & \\
\hline 3 & Eceran Sumatera & 10 & 0.349 & 0.466 & & 0.332 & & \\
\hline 4 & Ec_Palembang & 10 & & 1.804 & & 1.868 & 0.408 & 1.723 \\
\hline 5 & Harga GKP Sumater: & 10 & & & 0.759 & 1.227 & 0.408 & \\
\hline 6 & Grosir Sumatera & 10 & 0.349 & & & 0.437 & 0.819 & \\
\hline 7 & Harga PIBC & 10 & & 0.870 & 3.328 & 1.586 & & \\
\hline
\end{tabular}

The influence of Regency/City prices (retail, wholesale, and GKP) which was very small compared to the retail price of rice in the big cities of Sumatra (Padang, Palembang, and Bandar Lampung) shows the market dominance of these big cities. The inter-market price linkages of big cities in Sumatra become a determinant of price formation transmitted to other regency/city markets so that the influence of regency/city market prices is small. Big cities have bigger GRDP than other regencies/cities. According to Ismet et al. (1998) and Hidayanto et al. (2014), Gross per capita GRDP is significant and has a positive effect on the rice market integration in Indonesia. In addition, the regencey is an area with infrastructure conditions that tend to be less favorable than big cities. Infrastructure weaknesses (physical, commercial and institutional) increase transfer costs and inhibit the flow of prices and important information (Baquedano and Liefert, 2014; Varela et al, 2012; Siddique et al, 2008) resulting in this region not being a price determinant. 
International Journal of Social Science and Economic Research

ISSN: 2455-8834

Volume:05, Issue:09 "September 2020"

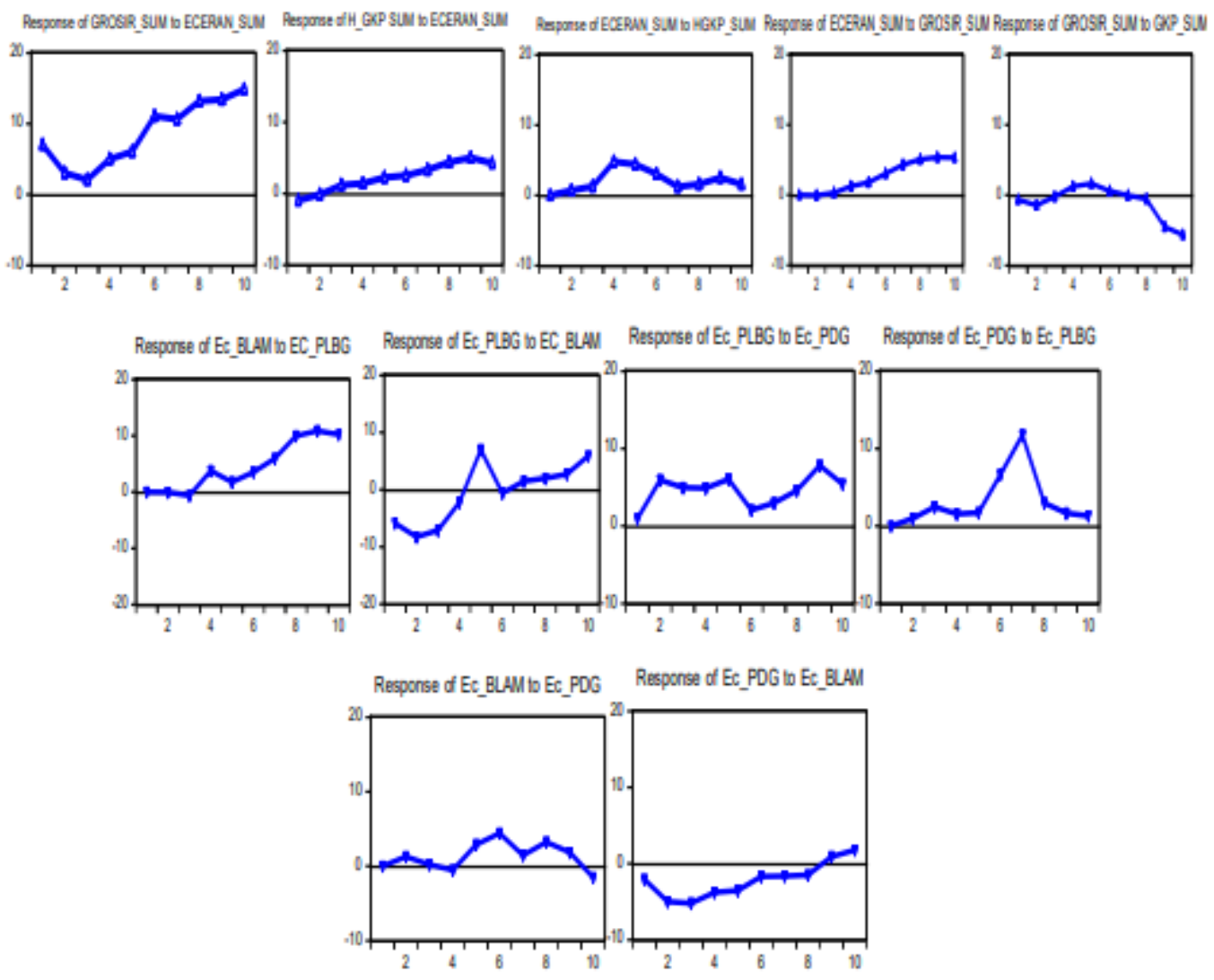

Figure 5.. Hubungan Harga GKP, Eceran, dan Grosir Beras Medium di Sumatera

This shows that there was a vertical imbalance in response between the GKP, wholesale and retail prices of the medium rice in Sumatra region. Retail prices were the prices that determine the formation of prices at the wholesale and producer levels because it responded to and are responded by the shock of GKP and wholesale prices, while the shock of GKP prices tend not to be responded to at the retail and wholesale levels. The response of the retail medium rice price among the major cities markets of the Sumatra region to the surprises in each market shows that the Palembang medium rice market has a strong response relationship with the Bandar Lampung and Padang markets. While the response relationship between the Bandar Lampung and Padang market was relatively weaker.

The retail price of Palembang medium rice affected the price of Bandar Lampung and Padang. The retail prices of Padang and Bandar Lampung medium rice only affected Palembang prices, while the retail prices of Padang and Bandar Lampung medium rice had a weak relationship. In addition, South Sumatra Province is the fourth largest province with a production surplus of $688,000 \mathrm{~kg}$. Lampung Province was also a province with a large surplus of 315,000 kg (Figure 5). These two surplus provinces are the determinants of the movement of goods and the formation of the medium rice retail price in Sumatra and other regencies/cities. 
International Journal of Social Science and Economic Research

ISSN: 2455-8834

Volume:05, Issue:09 "September 2020"

The Palembang medium rice market is a connecting link between producer and consumer prices and inter-regional hubs in Sumatra, so it can be concluded that Palembang is a reference market for medium rice in the Sumatra region. This is evidenced by the influence of the price of Palembang medium rice on an appreciable price of CRMM (3.328\%), while the CRMM price greatly affected the price of Padang medium rice $(9.364 \%)$ and Bandar Lampung medium rice $(1.072 \%)$.

\section{Java Island}

The retail price of Java medium rice is very responsive to the shock of the Java wholesale and GKP prices. The price shock of medium rice at the wholesale level in Java was also responded positively by Java retail prices and GKP prices. Similarly, the price shock of GKP was also responded positively by retail and wholesale prices. However, the response relationship between retail and wholesale prices and retail and GKP prices was stronger than the relationship between wholesale prices and GKP prices. This means that there is a balance in the direction of the vertical response starting from the price of GKP, wholesale and retail.

Retail prices determine the formation of prices at the wholesale and producer levels, as well as the influence of wholesale prices also determine prices at the retail and GKP levels, but the price response from the farmer level to the wholesaler and vice versa is relatively smaller. This happens because of the influence of the big traders' power as a determinant of the price so that the price shock at the wholesale level tends to be responded to weaker and requires a longer adjustment time by GKP prices in the farmer level. On the other hand, the shock of GKP and wholesale prices was responded to very strongly and quickly by prices in the retail level.
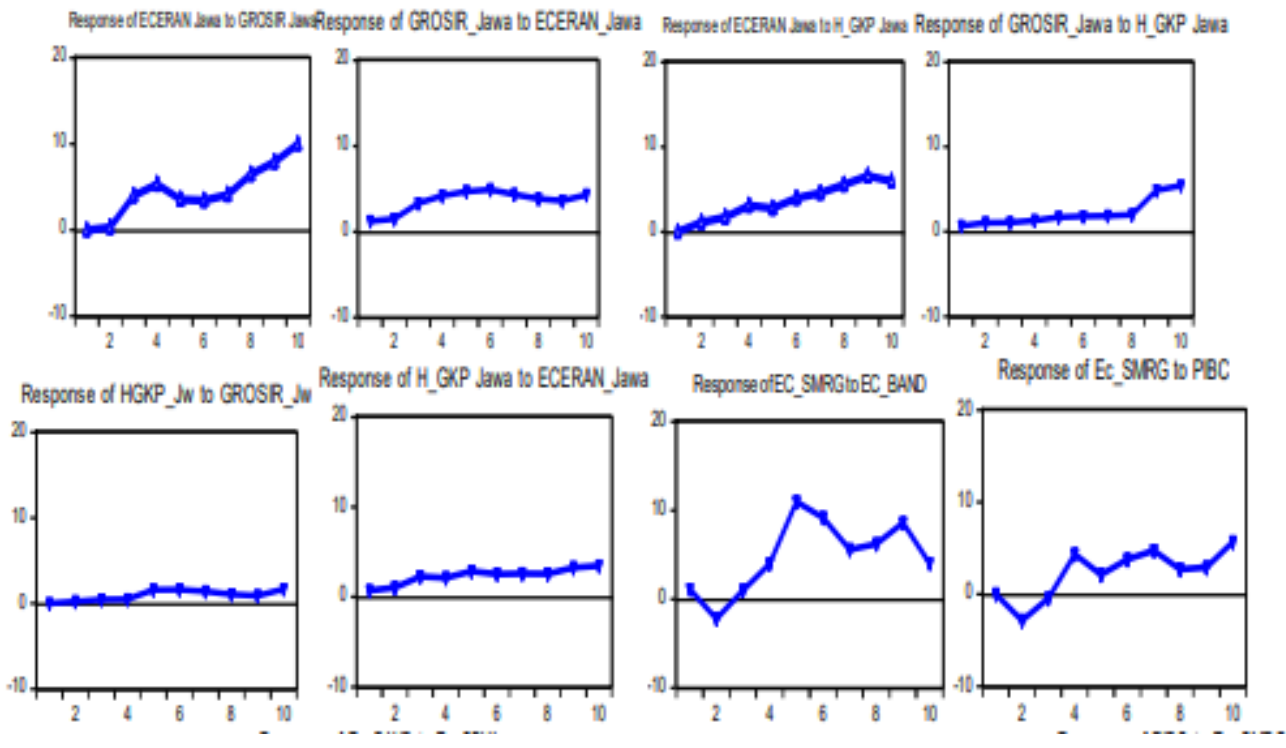


\section{International Journal of Social Science and Economic Research}

ISSN: 2455-8834

Volume:05, Issue:09 "September 2020"

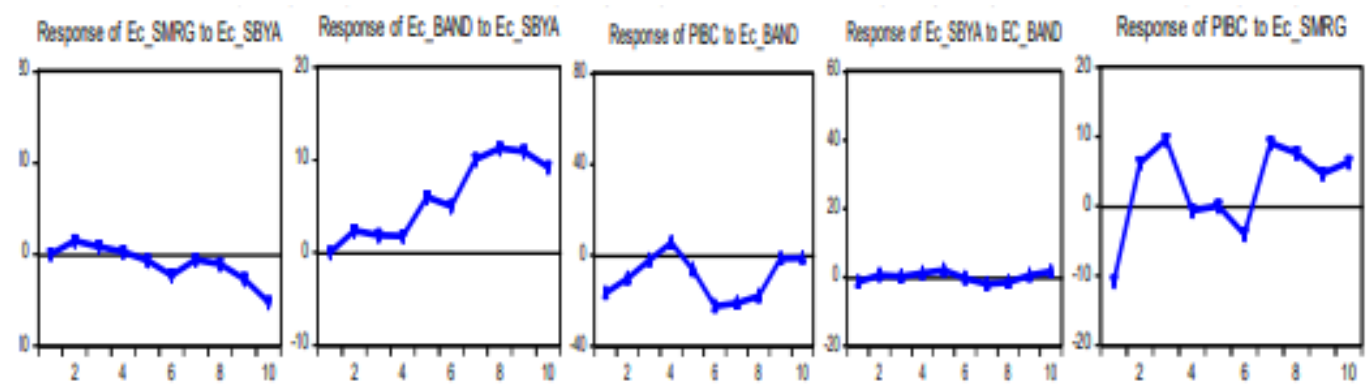

Gambar 7. Hubungan antara Harga GKP, Eceran, dan Grosir Beras Medium di Jawa

The relationship of the retail price response of CRMM and Bandung medium rice is very large (Figure 7). This is consistent with the FEDV results which show the effect of CRMM prices on Bandung retail prices of $8.271 \%$ and the effect of Bandung retail prices of $11,390 \%$ on CRMM prices. The retail price of Bandung medium rice also has a response relationship with Semarang retail prices which is in accordance with the FEDV results that shows the effect magnitude of Bandung retail prices of $4.903 \%$ on Semarang retail prices and the effect of Semarang retail prices of $10.853 \%$ on Bandung retail prices. Meanwhile, Surabaya retail prices showed the weakest relationship with other urban medium rice markets in the Java Island region. CRMM is the main reference price for rice in Java because it greatly affects the retail prices of all major cities in Java, including Surabaya $(2.172 \%)$. This can also be shown from the response of retail prices in Java, Bandung, Surabaya and Semarang to the shock of CRMM prices.

\begin{tabular}{clrrrrrrrr}
\hline No & \multicolumn{1}{c}{ Variabel } & $\begin{array}{c}\text { Variance } \\
\text { Period }\end{array}$ & PIBC & Ec_Band & Ec_Smrg & Ec_Sbya & $\begin{array}{c}\text { Eceran } \\
\text { Jawa }\end{array}$ & $\begin{array}{c}\text { Grosir } \\
\text { Jawa }\end{array}$ & $\begin{array}{c}\text { H_GKP } \\
\text { Jawa }\end{array}$ \\
\hline 1 & Eceran Bandung & 10 & 8.271 & & 10.853 & 3.625 & & & \\
2 & Eceran Semarang & 10 & 1.477 & 4.903 & & & & & 0.995 \\
3 & Eceran Surabaya & 10 & 2.172 & & 2.244 & & & & 0.398 \\
4 & Eceran Jawa & 10 & & & 0.148 & & & 0.988 & 0.570 \\
5 & Harga GKP Jawa & 10 & 1.296 & & 2.145 & & 0.422 & & \\
6 & Grosir Jawa & 10 & & 0.365 & 0.518 & & 0.437 & \\
7 & PIBC & 10 & & 11.390 & 3.055 & 3.463 & & & \\
\hline
\end{tabular}

\section{Other Regions}

Medium rice retail prices in other regions (Bali, Nusa Tenggara, Kalimantan, Sulawesi, Maluku and Papua) are very responsive to wholesale price shocks, but not responsive to GKP price shocks. Similarly, wholesale prices are also responsive to retail price shocks, but not responsive to GKP price shocks. This means that there is an imbalance in vertical response from producer prices (GKP), to the above market level, i.e., the wholesale and the retail markets. The retail price of medium rice in this region is the most responsive to the price shock of medium rice in the Makassar city market and the CRMM price. Based on the relationship among markets in the cities 
International Journal of Social Science and Economic Research

ISSN: $2455-8834$

Volume:05, Issue:09 "September 2020"

of Makassar, Mataram and Banjarmasin in this research model, the shock effect of Mataram medium rice prices is greatly responded to by the prices of Makassar and Banjarmasin medium rices.

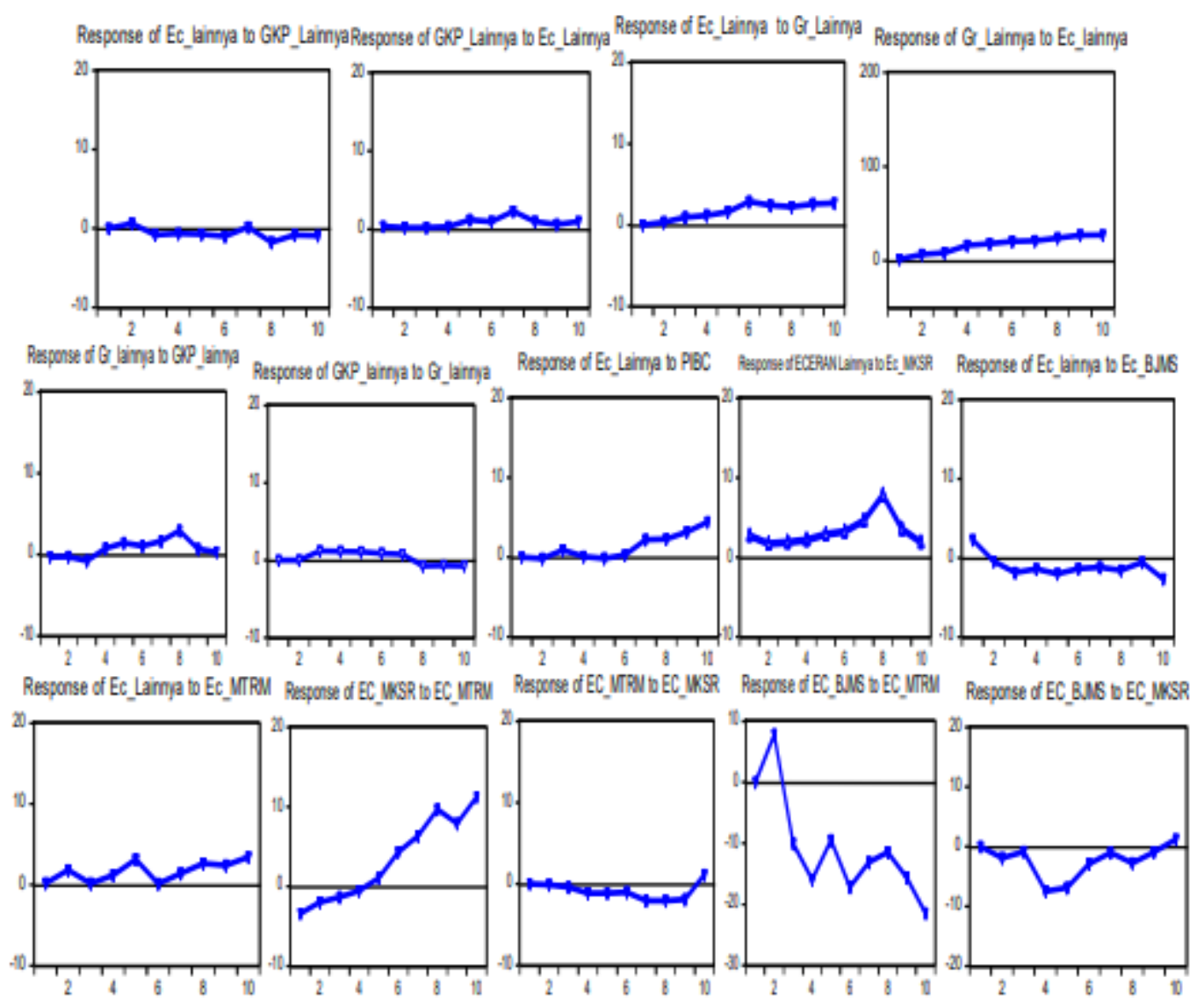

Gambar 8. Hubungan antar HGKP, Eceran, dan Grosir Beras Medium Wilayah Lainnya

The influence of the Mataram market on the medium rice market in other cities is also shown by the FEDV results. The Mataram medium rice market greatly affected the medium rice market in Banjarmasin City (14.666\%) and Makassar City (1.523\%). For the retail price in this region, it is most influenced by Makassar retail prices (0.427\%) and CRMM prices $(0.1825 \%)$. This corresponds to the shock at Makassar retail and the CRMM prices which has been responded positively by the region's retail prices (Figure 3). 
International Journal of Social Science and Economic Research

ISSN: 2455-8834

Volume:05, Issue:09 "September 2020"

\begin{tabular}{llrrrrrrrrr}
\hline No & \multicolumn{1}{c}{ Variabel } & & $\begin{array}{c}\text { Variance } \\
\text { Period }\end{array}$ & PIBC & Ec_Mksr & Ec_Bjms & Ec_Mtrm & Eceran & Grosir & GKP \\
\hline 1 & Ec_Makassar & 95,669 & 10 & 1,492 & & & 1,523 & & & 0,738 \\
2 & Ec_Banjarmasin & 66,665 & 10 & 9,867 & 1,027 & & 14,663 & & & \\
3 & Ec_Mataram & 90,505 & 10 & 4,140 & 0,138 & 2,567 & & & & 2,134 \\
5 & Eceran & 99,007 & 10 & & 0,428 & & 0,130 & & 0,122 & \\
6 & Grosir & 97,925 & 10 & & 0,255 & 0,281 & & 1,359 & & \\
7 & Harga GKP & 97,699 & 10 & & & & 1,476 & 0,056 & 0,037 & 0,098 \\
8 & Harga PIBC & 51,395 & 10 & & 13,129 & 4,251 & 30,295 & 0,142 & & \\
\hline
\end{tabular}

Therefore, the Makassar medium rice market becomes a decisive market and a reference for other regency/city markets in this region. However the influence of the Mataram market also determines and becomes a reference for the Banjarmasin city and Makassar city medium rice markets. Considering the condition of the regions in Eastern Indonesia which has archipelagic and regional deficit characteristics, the Makassar and the Mataram medium rice markets can be used as a reference market for other regency/city medium rice markets in this region.

\section{Indonesia}

In the national aggregate, the retail price of medium rice is very responsive to wholesale price shock, but not responsive to GKP price shock. Similarly, wholesale prices are also responsive to retail price shock, but not responsive to GKP price shock. This means that nationally, an imbalance occurs in vertical response from producer prices (GKP), to the above market level, i.e., the wholesale market and the retail market. The retail price becomes the price that determines the price formation at the wholesale and producer levels because it responds and is responded to wholesale price shocks. Similarly, the wholesale price of medium rice also has a respond and is responded by retail price shocks. However, national GKP prices tend to be less responsive to retail and wholesale price shocks, as well as retail and wholesale price shocks also tend to be less responded by GKP prices. 


\section{International Journal of Social Science and Economic Research}

ISSN: 2455-8834

Volume:05, Issue:09 "September 2020"

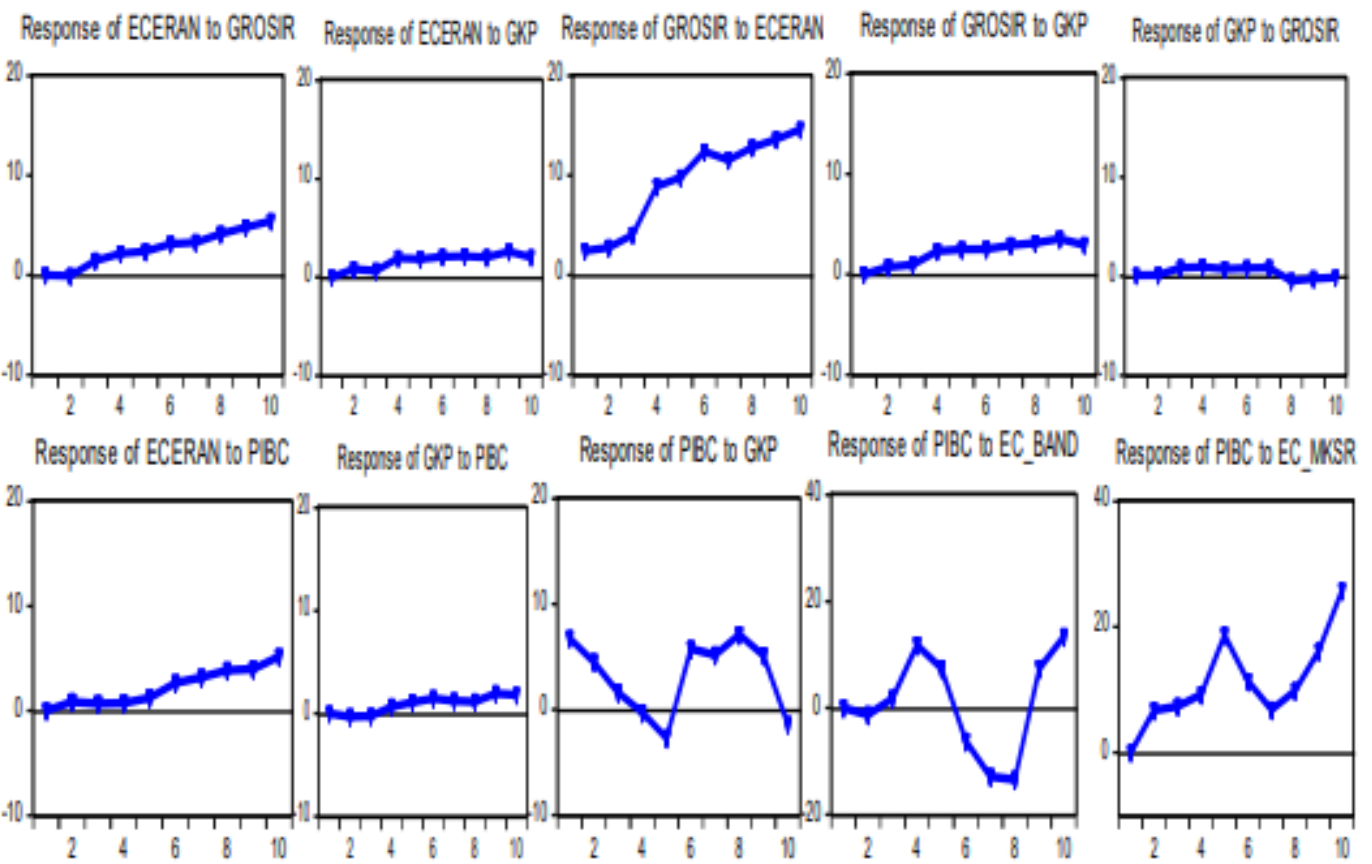

Gambar 9. Hubungan antar HGKP, Eceran, dan Grosir Beras Medium Indonesia

CRMM prices greatly affect the retail price of Indonesian medium rice. The CRMM price shock was greatly responded by retail prices. However, the retail price shock was not responded well by the CRMM price. Likewise, the price of the CRMM price was strongly responded by the retail price, but the price shock of the GKP was less responded by the price of the CRMM. This happens because of the strong effect of the influence of big traders who are represented by the CRMM market in determining prices. Big traders as determinants of prices result in vertical transmission of prices becoming unbalanced. The transmission of a shocking rise in CRMM prices to producer prices tends to be slow, while price shocks at the producer level are transmitted quickly to consumer prices, especially big traders (CRMM). Spatially, CRMM has the greatest response relationship with the Bandung and Makassar medium rice markets.

Based on the analysis by region and the analysis of Indonesian aggregate, the CRMM price becomes a reference for national retail and wholesale prices in other major cities. The retail prices of Bandung and Makassar are the most influential prices on prices in other cities. Bandung is the most influential in Java Island, while Makassar is the most influential outside Java and Sumatra Islands. Surabaya is more related to Makassar (5.335\%) than other cities in Java Island (Table 6). This means that East Java's production surplus has mostly flowed to areas outside of Java Island. Together with the supply of South Sulawesi meeting the needs of rice consumption in the deficit region in Eastern Indonesia. Hernandez- Villafuerte (2012) mentioned that the market is less integrated due to the market location close to the port or neighboring countries. This causes 


\section{International Journal of Social Science and Economic Research}

ISSN: $2455-8834$

Volume:05, Issue:09 "September 2020"

Surabaya medium rice market to be less integrated with the Java Island region.

\begin{tabular}{|c|c|c|c|c|c|c|c|c|c|c|}
\hline No & Variabel & $\begin{array}{c}\text { Variance } \\
\text { Period }\end{array}$ & $\mathrm{PIBC}$ & Ec_Plbg & Ec_Band & Ec_Sbya & Ec_Mksr & Eceran & Grosir & GKP \\
\hline 1 & Ec_Palembang & 10 & 5.782 & & 3.134 & & 14.678 & & & \\
\hline 2 & Ec_Bandung & 10 & 17.379 & & & 0.888 & 3.344 & & & \\
\hline 3 & Ec_Surabaya & 10 & 1.464 & 2.016 & & & 5.335 & & & \\
\hline 4 & Ec_Makassar & 10 & & & 15.552 & 2.356 & & & 1.795 & \\
\hline 5 & Eceran & 10 & 0.203 & & & & & & 0.265 & 0.083 \\
\hline 6 & Grosir & 10 & 0.124 & & & & & 0.698 & & \\
\hline 7 & Harga GKP & 10 & & 0.186 & & 0.185 & & & & \\
\hline 8 & Harga PIBC & 10 & & & 4.227 & 1.139 & 8.930 & & & \\
\hline
\end{tabular}

Makassar's dominance of a large influence is thought to occur due to its strong relationship with the CRMM. Makassar affects the CRMM price change of $8.930 \%$. This is consistent with Cipinang Food Station data which stated that South Sulawesi rice supply reached $26.9 \%$ of the total supply to CRMM in 2018.

Makassar retail price is strongly influenced by Bandung prices $(15.522 \%)$ because the amount of rice supply from South Sulawesi to the CRMM (which is the reference price of rice at all levels and regions in Indonesia) is highly dependent on West Java production capability as the main supplier of rice. Bandung retail prices are strongly influenced by the CRMM (17.379\%). In addition, South Sulawesi is a major supplier for the Sumatra region (Susilowati, 2017). Of the $56.27 \%$ South Sulawesi rice flowing out of the province, $14.85 \%$ of it flowed into Sumatra (BPS, 2018a). This causes Makassar retail prices greatly affect price changes in Sumatra including Palembang retail prices $(14.678 \%)$.

Based on the findings and discussions above, it can be concluded that the main markets for medium rice reference in Indonesia are: (1) CRMM which affects retail prices in all regions and major cities; (2) Palembang which is a big city market in the largest surplus province in the Sumatra region. In addition, Palembang is spatially closely related to Bandar Lampung which is also a surplus area and the northern region of Sumatra which in aggregate is a deficit area; (3) Bandung becomes the reference market for West Java Province which is the second largest rice producer after East Java Province. West Java spatial relationship with CRMM is an important factor for Bandung as a reference market because as much as 51.6\% of total CRMM supply comes from West Java Province; (4) Surabaya plays an important role as a reference market because the response relationship and its influence is very strong with the medium rice market in other major cities through the Makassar City market. Surabaya has spatial interrelationships with other regions because the supply of rice to this region mostly comes from East Java. (5) Makassar is the largest city in Sulawesi which is the biggest national surplus area. Sulawesi rice surplus is 2.32 million tons or around $81.23 \%$ of the total national rice surplus, so that it becomes the center of the goods flow to other regions in Eastern Indonesia. 
International Journal of Social Science and Economic Research

ISSN: 2455-8834

Volume:05, Issue:09 "September 2020"

\section{CONCLUSIONS AND RECOMMENDATIONS}

\section{Conclusions}

There is spatial integration among markets in medium rice commodities both regionally and nationally as indicated by the existence of long-term cointegration in the analysis of regional disaggregates and national aggregates. However, the vertical integration of the medium rice market only occurs in the Java Island region; while in regions outside Java, there is an imbalance among producer, wholesale and retail prices. Based on the influence of market forces, total production, surplus/deficit and spatial linkages, then (a) Cipinang Rice Main Market (CRMM) is the Indonesia medium rice reference market, (b) Palembang is the medium rice reference market in Sumatra, (c) Bandung and Surabaya are the medium rice reference market in Java Island region, (d) Makassar is the medium rice reference market in Eastern Indonesia region.

\section{Recommendations}

Variations among regions and times cause a region of surplus and deficit in certain periods and throughout the year. Storage (reserves and stocks) is an important factor because supplies to the deficit region and supplies in the deficit period can be carried out by distributing the results of the storage. Reserve and stock management is carried out in the medium rice reference market for each region. In addition, the management of food reserves in the reference market, the management of Government Food Reserves, Regional Government Food Reserves and Community Food Reserves can be instruments of controlling the stabilization of supply and prices of medium rice. The development of these reserves and stocks will then become a regional food hub for each region which becomes the link of supply among surplus and deficit areas, inter-regencies/inter-cities, inter-provinces and islands.

\section{References}

Adenegan KO. 2012. Spatial price analysis of tomatoes in Nigeria. Int J Manage Market. 5(2):31-38 Barrett CB, Li JR. 2002. Distinguishing between equilibrium and integration in spatial price analysis.Am J Agric Econ. 84:292-307

Baquedano, FG. Liefert, WM., 2014. Market integration and price transmission in consumer markets of developing countries. Food Policy 44 (2014) $103-114$.

Engle RF, Granger CWJ. 1987. Co-integration and error correction: representation, estimation, and testing. Econometrica. 55(2): 251-276

Granger CWJ, Newbold P. 1974. Spurious regression in econometrics. J Econometrics. 
International Journal of Social Science and Economic Research

ISSN: 2455-8834

Volume:05, Issue:09 "September 2020"

\section{2(2):111- 120}

[BPS] Badan Pusat Statistik. 2018a. Distribusi Perdagangan Komoditas Beras Indonesia Tahun 2018. Badan Pusat Statistik. Tersedia di https://www.bps.go.id/publication/2019/02/26/f115a20571c61a305c69ebd7/ distribusi-perdagangan-komoditas-beras-di-indonesia-2018.html

[BPS] Badan Pusat Statistik, 2018b. Luas panen dan Produksi Beras di Indonesia: Hasil Kegiatan Pendataan Statistik Pertanian Tanaman Pangan Terintegrasi Dengan Metode Kerangka Sampel Area.Tersedia di https://www.bps.go.id/publication/2018/12/21/543c607a9ce62960d929060f/1 uas-panen-dan-produksi-beras-di-indonesia-2018--hasil-kegiatan-pendataanstatistik-pertanian-tanaman-pangan-terintegrasi-dengan-metode-kerangkasampel-area-.html

Borensztein, E., Khan, M.S., Reinhart, C.M., dan Wickham, P. 1994. The Behavior of Non-oil Commodity Prices. Occasional Paper No.112, International Monetary Fund, Washington.

Crucini MJ, Shintani MT, Tsuruga. 2010. The law of one price without the border: the role of distance versus sticky prices. Econ J. 120: 462-480.

Edi, Sirojuzilam, Rahmanta. 2014. Analisis integrasi dan volatilitas harga beras regional ASEAN terhadap pasar beras Indonesia. J Ekon. 17(2): 126-139.

Firdaus M, Gunawan I. 2012. Integration among regional vegetable markets in Indonesia. J. ISSAAS.18(2):96-106

Ghafoor A, Aslam M. 2012. Market integration and price transmission in rice markets of Pakistan. South Asia Network of Economic Research Institute Working Paper No.12. Islamabad (PK): South Asia Network of Economic Research Institute Gluschenko K. 2018. Spatial integration of siberian regional markets. MPRA Paper No. 85667. Novosibirsk (RU): Institute of Economics and Industrial Engineering, Siberian Branch of the Russian Academy of Sciences and Novosibirsk State University.

Goletti F, Ahmed R, Farid N. 1995. Structural determinant of market integration: the case study of rice in Bangladesh. Dev Econ. 33(22):185-202. Johansen S. 1988. A Statistical analysis of co-integration vectors. J Econ Dynamics 
International Journal of Social Science and Economic Research

ISSN: 2455-8834

Volume:05, Issue:09 "September 2020"

Control. 12(2-3):231-254.

Hernandez-Villafuerte K. 2012. Relationship between spatial price transmission and geographical distance in Brazil. Paper presented at the Internatioal Association of Agricultural Economist (IAAE) 2012 Congress Change and Uncertainty.

Hidayanto MW, Anggraeni L, Hakim DB. 2014. Faktor penentu integrasi pasar beras di Indonesia.Pangan. 23(1):1-16.

Ismet M, Adrew PB, Richard VL. 1998. Goverment intervention and market integration in Indonesia rice markets. Agricultural Economics. 19(3): 283- 295.

Katrakilidis C. 2008. Testing for market integration and the law of one price: an application to selected European milk markets. Int J Econ Res. 5(1):93-104.

Monke E, Petzel T. 1984. Market integration: an application to international trade in cotton. Am J Agric Econ. 66(4):481-487

Negassa A, Meyers R, Gabre-Mahdin E. 2003. Analyzing Grain Market Efficiency in Developing Countries: Review of Existing Methods and Extensions of the Parity Bound Model. Markets, Trade, and Institutions Division Discussion Paper No. 63. Washington, DC (US): International Food Policy Research Institute.

Pavel V, Barry KG. 2005. Analysis of price transmission along the food chain. OECD Food, Agriculture and Fisheries Working Papers 3. Paris (FR): OECD Publishing

Ravallion M. 1986. Testing market integration. Am J Agric Econ. 68(1): 102-109

Rapsomanikis G, Hallam D, Conforti P. 2006. Market integration and price transmission in selected food and cash crop markets of developing countries: review and applications. In: Sarris A, Hallam D, editors. Agricultural commodity market and trade: new approaches to analyzing market structure and instability. Rome (IT): Food and Agriculture Organization of the United Nations. p. 187-217.

Sanogo, I., dan M. Maliki Amadou. 2010. Rice market integration and food security in Nepal: The role of cross-border trade with India. Food Policy 35(4): 312-322. 
International Journal of Social Science and Economic Research

ISSN: 2455-8834

Volume:05, Issue:09 "September 2020"

Sexton RJ, Sheldon IM, McCorriston S, Wang H. 2004. Analyzing vertical market structure and its implications for trade liberalization. AAEA Annual Meetings; 2004 June; Denver, Colorado, United States of America

Sharp P, Uebele M. 2013. Rural infrastructure and agricultural market integration in the united states: a long run perspective. Discussion Papers on Business and Economics. Odense (DK): University of Southern Denmark.

Siddique MAB, Raha SK, Alam MS. 2008. Market integration: an application of cointegration and error correction model to rice markets in Bangladesh. The Agriculturists. 6(1\&2): 90-98.

Susilowati, SH., 2017. Perdagangan Antarpulau Beras di Provinsi Sulawesi Selatan. Analisis Kebijakan Pertanian, Vol. 15. No.1, Juni 2017: 19-42.

Tsimpo C \& Wodon Q, 2008. Rice prices and poverty in Liberia. Available at http://elibrary.worldbank.org/doi/abs/10.1596/1813-9450-4742 (Diunduh 30 Sept 2018).

Tomek W, Robinson KL. 1990. Agricultural Product Prices. London (GB): Cornell University Press.

Udoh E.J, Sunday B.A. 2007. Estimating exportable tree crop relative price variability and inflation movement under different policy regimes in Nigeria. European $\mathbf{J}$ Soc Sci. 5(2):17-26.

Varela GE, Aldaz-Carrol, Lacovone. 2012. Determinants of market integration and price transmission in Indonesia. Policy Research Working Paper The World Bank No. 6098.

Vasciaveo M, Rosa F, Weaver R. 2013. Agricultural market integration: price transmission and policy intervention. Paper prepared for presentation at the 2nd AIEAA Conference on Between Crisis and Development: Which Role for the Bio-Economy; 2013 Jun 6-7; Parma, Italy

Zunaidah AD, Setiawan B, Anindita R. 2015. Analisis integrasi pasar apel. Habitat. 26(3):183-194 